\title{
FLIPPED CLASSROOM AND KAHOOT IN PHYSICS LEARNING: IMPROVING STUDENTS' MOTIVATION LEARNING
}

\author{
Irnin Agustina Dwi Astuti 1*, Yoga Budi Bhakti2, Ria Asep Sumarni ${ }^{3}$, Dwi Sulisworo4, M. Toifur ${ }^{5}$ \\ 1,2,3 Universitas Indraprasta PGRI, Jakarta, Indonesia \\ 4,5 Universitas Ahmad Dahlan, Yogyakarta, Indonesia \\ *irnin.agustina@gmail.com
}

\begin{tabular}{l}
\hline Article Info \\
\hline Article history \\
Received January 21, 2021 \\
Revised January 23, 2021 \\
Accepted February 22, 2021 \\
\hline
\end{tabular}

Keywords: Flipped classroom; Kahoot; Physics learning; Students' motivation for learning.

\begin{abstract}
Ideal condition in physics learning should combine concepts with technology. Traditional physics learning causes students to be not interested in learning physics. There must be innovations in physics learning in order to be more interactive learning. One of them flipped classroom learning. Flipped classroom learning combined with Kahoot online games, will make students more active. The purpose of this research is to increase students' learning motivation with Kahoot-based flipped classroom learning. The method used in this research is the quasi-experimental method with the research design of The Randomized Posttest Only Control Group Design. The research finding can describe as follows: First, the flipped classroom is learning the model that combines face-to-face with e-learning to improve students' motivation in physics learning. Second, Kahoot in a flipped classroom supported as an evaluation model. Third, three main steps in applying the flipped classroom are preparing, implementing, and evaluating the design.
\end{abstract}

\section{INTRODUCTION}

Motivation is an internal process that activates, guides, and maintains behaviour over time. Each student has a different learning motivation. Therefore, every teacher must understand this so that the learning activities are not wrong (Bhakti et al., 2018). Teachers who ignore the problem of motivational differences tend to fail to carry out their teaching duties. The motivation of students' learning will have a positive effect when the right learning environment is provided so that students can learn to the maximum, which ultimately impacts the learning outcomes (Changeiywo et al., 2011). If students face conditions that do not match their learning motivation, they cannot learn to the maximum. So it negatively impacts the learning outcomes. Motivation is an intense desire or passion that encourages the person to try and do something to succeed. Motivation is a critical factor in keeping students in their learning process and is the most significant factor that impacts the learning process (Saleh, 2014) (Argaw et al., 2017).

Physics learning should require many teachers to innovate in developing learning media that students can love. Students' interest in studying physics is low; many students do not like physics because there are too many formulas and very abstract materials. Based on observations in several schools in the Jakarta area found problems in learning physics. There 
are low students learning motivation, many students who do not focus on learning physics, and monotonous teacher learning methods. Therefore students are less active and cause student learning interest also to below. Overall, teachers already use technology to support the learning process, but technology is only displaying powerpoints and learning videos. This situation causes physics learning to become monotonous and makes students quickly bored. Therefore, an innovative learning medium needs to enable students and increase students' learning motivation. The selection of learning media determines physics's quality and learning process (Ariyani et al., 2018; Liliarti \& Kuswanto, 2018).

Physics' teaching provides the learners with understanding skills and scientific knowledge needed for scientific research (Sahin, 2010). The adoption of diverse learning contexts, learning and teaching strategies, and assessment practices stimulates students' interest and motivation for learning (Jimoyiannis \& Komis, 2001). Physics learning is enjoyable when displaying learning media that corresponds to technology's development (Bhakti et al., 2020) (Putra \& labal, 2014). One of the learning media that can be used to increase the learning motivation with Kahoot.

Kahoot! is a digital game-based student response system that allows teachers and learners in classroom settings to interact through competitive knowledge games using existing infrastructure (Lin et al., 2018). Kahoot! It represents a new generation of student response systems that focuses on student motivation and engagement through gamification (Wulandari et al., 2016). This platform is apt for increasing motivation and engagement (which promotes learning) and assessing students' understanding of a lesson (ZarzyckaPiskorz, 2016). Furthermore, gamification develops learners' metacognitive abilities, promotes empathy, and builds teamwork skills.

Media learning with Kahoot can apply in flipped classroom learning. Flipped learning combines meetings in a classroom with online learning (Bhakti et al., 2019). According to Herreid \& Schiller, in flipped learning, things usual in the classroom, such as explaining the material, giving assignments, exercises, and house assignments on the move, become an online study (Herreid \& Schiller, 2013). Flipped classroom learning can increase student learning independence and student learning motivation (Yilmaz, 2017; Awidi \& Paynter, 2019). Students become active and can learn independently (Jamaludin \& Osman, 2014). Flipped classroom learning can support free learning.

\section{METHODS}

The method used in this research is quasi-experiment with pre-test post-test of nonequivalent control group design research. The author provides a pre-test and post-test to measure students' motivation before and after applying the treatment. Instruments used are student learning motivation questionnaires in the form of a checklist with a Likert scale. There are about 25 instruments of learning motivation, and it showed in Table 1. 
Table 1. Grid of learning motivation instruments

\begin{tabular}{lll}
\hline Indicator & Description & $\begin{array}{l}\text { Number of } \\
\text { statements }\end{array}$ \\
\hline Attention & The pleasure of the lesson & 2 \\
& Attention to tasks & 2 \\
\multirow{3}{*}{ Relevance } & Accuracy in completion of tasks & 1 \\
& Understand materials in the classroom & 2 \\
& Linking lessons with daily life & 1 \\
Confidence & Conformity of learning methods & 4 \\
& Confidence in understanding the lesson & 3 \\
& Goals & 2 \\
Satisfaction & Confident in classroom & 1 \\
& Satisfaction with learning outcomes & 2 \\
& Attendance in the classroom & 6 \\
\hline
\end{tabular}

This motivational instrument of learning given to students before and after the study flipped classroom with Kahoot. Before the motivation sheet of learning is disseminated to students first in the validity and reliability test. The data analysis techniques used are average analysis and the $\mathrm{N}$ gain test.

The learning motivation questionnaire results used to measure the level of students' motivation in learning science. The learning motivation questionnaire results were analysed and converted into poor, low, medium, high, and excellent categories.

\section{RESULTS AND DISCUSSION}

Flipped classroom with Kahoot held in SMP N 103 Jakarta. Students are motivated to learn to know the student's early learning motivation, following the motivational results of education before flipped classroom learning.

Table 2. Value of learning motivation before flipped classroom with Kahoot

\begin{tabular}{lll}
\hline No & Indicator & Value \\
\hline 1. & Attention & 1.6 \\
2. & Relevance & 2.1 \\
3. & Confidence & 2.2 \\
4. & Satisfaction & 2.3 \\
Average & 2.05 \\
\hline
\end{tabular}

Based on Table 2, the average student's learning motivation was 2.05, including the low category. In terms of attention, students' delight in science lessons has not yet appeared. Students are also still indifferent to the task, so it is not time to collect their assignments. The material connection conveyed is not fully understood in the relevance aspect, so many 
students still do not understand the material. In the confidence aspect, there are still many students who are not confident in studying physics. Students find physics complicated to learn. In terms of satisfaction, students have not been satisfied with the physics study because they have not understood it well. There has not been encouragement or interest in physics learning, so students in the class are still passive in physics.

The physics learning with flipped classroom and Kahoot held in 2 months. Flipped classroom learning offers a mix of online learning and face-to-face learning. At the time of online learning, teachers provide materials using LMS, namely Edmodo. After that, when face-to-face learning in the classroom, the teacher held discussions and games using Kahoot.

At the core activity, the teacher started the learning by using Kahoot media by opening the page and connecting the projector LCD. Using the Kahoot app, the teacher acted as the quiz organiser (quiz host) by accessing https://Kahoot.com/, then selected the Kahoot to be used and chose the game mode. There were two game modes, namely classic mode and team mode. Classic mode is an individual quiz game where each student could be a quiz participant and competes with other participants. In contrast, the team mode is a group quiz game where students can work together to answer the quiz competitively.

When the teacher hosted the quiz, a pin code appeared, which the students then inputted to enter the quiz game. When all participants had registered in the game, the teacher started the Kahoot Quiz. The students answered by pressing the selection button, as can be seen on the projector screen. In the team mode, students can discuss to determine which answer is the most appropriate. However, it must do faster because there are time constraints on the questions. The students were asked to open the page http://kahot.it/ and entered the pin based on the teacher's direction. Then students tried to answer multiplechoice and true and false questions. The value of learning motivation after flipped classroom with Kahoot showed in Table 3.

Table 3. Value of learning motivation after flipped classroom with Kahoot

\begin{tabular}{lll}
\hline No & Indicator & Value \\
\hline 1. & Attention & 3.6 \\
2. & Relevance & 3.2 \\
3. & Confidence & 3.4 \\
4. & Satisfaction & 3.5 \\
& Average & 3.42 \\
\hline
\end{tabular}

Based on Table 3, the average student's learning motivation was 3.42, which included in the high category. The implementation of physics learning using Kahoot media can 
increase motivation to learn physics in students. Students in learning try to work on Kahoot quiz questions and compete with other groups. It motivates students to learn physics because they do not want to lose other group friends. According to Graham, games with Kahoot in the classroom increase student motivation and engagement and ultimately improve learning (Graham, 2015). Purba explains Kahoot! is fun, informative, helpful, perfect, and pleasant to learn in the class (Purba et al., 2019). According to Plump \& Larosa, Kahoot! Requiring the instructor or the training of students is limited; it is a means to provide vitality, student participation, and meta-cognitive support to class (Plump \& LaRosa, 2017). Students can be more willing to express their opinions on material that they feel has less understanding. In line with research, game-based learning positively affects student motivation (Wichadee \& Pattanapichet, 2018; Papastergiou, 2009).

Using the flipped classroom can build the students' motivation in the classroom. The teacher can teach using the textbook and technology device (Sulisworo, 2018). Flipped classroom learning using Kahoot is a blend of learning with technology media that is very suitable for this day and age. The learning evaluation model with games education is ideal for face-to-face learning.

Third, three main steps in applying the flipped classroom are preparing, implementing, and evaluating the design. Kahoot, which is one of the game-based learning media, encourages the climate of student competition during the learning process (Chaiyo \& Nokham, 2017; Licorish et al., 2017). With this climate, teachers become more accessible to manage learning classes according to the established fundamental competencies. This application's prestige and achievement elements encourage students to continue to spur themselves in exploring knowledge and improving competency (Mada \& Anharudin, 2019; Blondy, 2007).

The visual display resulting from students' answers can measure how much learning materials students already understand. The evaluation process is an essential element to know the teaching-learning process's success rate and feedback on the following learning process (Kirkwood \& Price, 2014). The entire evaluation process results can utilise the importance of improvement and enrichment of learning so that learning completeness can achieve the maximum (Chen \& Hoshower, 2003).

The application of flipped classroom learning models makes teachers more interactive with students and can create a variety of conditions and situations in learning both at home and in the classroom in order to produce changes that fit the purpose, both the results of learning and thinking abilities (Sumarni et al., 2020). Flipped classroom learning combined with Kahoot can activate students' learning activity. Flipped classrooms can make students study independently and are not dependent on teachers. Following the development of the era and technology, Kahoot-based flipped classroom learning was very supportive in industrial revolution 4.0. 


\section{CONCLUSION}

The research finding can describe as follows: First, the flipped classroom is learning the model that combines face-to-face with e-learning to improve students' motivation in physics learning. Second, Kahoot in a flipped classroom supported as an evaluation model. Third, three main steps in applying the flipped classroom are preparing, implementing, and evaluating the design.

\section{ACKNOWLEDGEMENTS}

We want to thank and appreciate to Ministry of Research and Higher Education of Republic Indonesia for this research funding through the grant of Higher education institution collaboration (Penelitian Kerjasama Peguruan Tinggi) for the year 2020. This research supported by LLDIKTI III, LPPM Universitas Indraprasta PGRI, and Universitas Ahmad Dahlan.

\section{REFERENCES}

Argaw, A. S., Haile, B. B., Ayalew, B. T., \& Kuma, S. G. (2017). The effect of problem-based learning (PBL) instruction on students' motivation and problem-solving skills of physics. Eurasia Journal of Mathematics, Science and Technology Education, 13(3), 857-871. https://doi.org/10.12973/eurasia.2017.00647a

Ariyani, F., Nayana, T., Saregar, A., Yuberti, Y., \& Pricilia, A. (2018). Development of Photonovela with Character Education: As an Alternative of Physics Learning Media. $\begin{array}{lllll}\text { Jurnal Ilmiah Pendidikan Fisika } & 227 .\end{array}$ https://doi.org/10.24042/jipfalbiruni.v7i2.3072

Awidi, I. T., \& Paynter, M. (2019). The impact of a flipped-classroom approach on student learning experience. Computers \& Education, 128, 269-283.

Bhakti, Y. B., Astuti, D., \& Agustina, I. (2018). The influence process of science skill and motivation learning with creativity learn. Journal of Education and Learning, 12(1), 3035.

Bhakti, Y. B., Astuti, I. A. D., \& Rahmawati, E. Y. (2020). Improving Students' Problem Solving Ability Through Learning-Based Videoscribe. JIPF (Jurnal Ilmu Pendidikan Fisika), 5(2), 61. https://doi.org/10.26737/jipf.v5i2.1595

Bhakti, Y. B., Astuti, I. A. D., Sumarni, R. A., Sulisworo, D., \& Toifur, M. (2019). Flipped Classroom as a Millenial Teaching Model. Indonesian Review of Physics, 2(1), 22-27.

Blondy, L. C. (2007). Evaluation and application of andragogical assumptions to the adult online learning environment. Journal of Interactive Online Learning, 6(2), 116-130.

Chaiyo, Y., \& Nokham, R. (2017). The effect of Kahoot, Quizizz and Google Forms on the student's perception in the classrooms response system. 2nd Joint International Conference on Digital Arts, Media and Technology 2017: Digital Economy for Sustainable Growth, ICDAMT 2017, 178-182. https://doi.org/10.1109/ICDAMT.2017.7904957 
Changeiywo, J. M., Wambugu, P. W., \& Wachanga, S. W. (2011). Investigations of students' motivation towards learning secondary school physics through mastery learning approach. International Journal of Science and Mathematics Education, 9(6), 13331350. https://doi.org/10.1007/s10763-010-9262-z

Chen, Y., \& Hoshower, L. B. (2003). Student evaluation of teaching effectiveness: An assessment of student perception and motivation. Assessment \& Evaluation in Higher Education, 28(1), 71-88.

Graham, K. (2015). TechMatters: Getting into Kahoot! (s): Exploring a Game-Based Learning System to Enhance Student Learning. Alex Quarterly, 42(3), 6-7. http://commons.emich.edu/cgi/viewcontent.cgiearticle=1272\&context=loexquarterly

Herreid, C. F., \& Schiller, N. A. (2013). Case Studies and the Flipped Classroom. Journal of College Science Teaching, 42 (5), 62-66.

Jamaludin, R., \& Osman, S. Z. M. (2014). The use of a flipped classroom to enhance engagement and promote active learning. Journal of Education and Practice, 5(2), 124-131.

Jimoyiannis, A., \& Komis, V. (2001). Computer simulations in physics teaching and learning: A case study on students' understanding of trajectory motion. Computers and Education, 36(2), 183-204. https://doi.org/10.1016/S0360-1315(00)00059-2

Kirkwood, A., \& Price, L. (2014). Technology-enhanced learning and teaching in higher education: what is "enhanced" and how do we know? A critical literature review. Learning, Media and Technology, 39(1), 6-36. https://doi.org/10.1080/17439884.2013.770404

Licorish, S. A., George, J. L., Owen, H. E., \& Daniel, B. (2017). "Go Kahoot!" Enriching classroom engagement, motivation and learning experience with games. Proceedings of the 25th International Conference on Computers in Education, ICCE 2017 - Main Conference Proceedings, December, 755-764.

Liliarti, N., \& Kuswanto, H. (2018). Improving the Competence of Diagrammatic and Argumentative Representation in Physics through Android-based Mobile Learning Application. International Journal of Instruction, 11 (3), 106-122.

Lin, D. T. A., Ganapathy, M., \& Kaur, M. (2018). Kahoot! It: Gamification in higher education. Pertanika Journal of Social Sciences and Humanities, 26(1), 565-582.

Mada, R. D., \& Anharudin, A. (2019). How Online Learning Evaluation (Kahoot) Affecting Students' Achievement and Motivation (Case Study on it Students). International Journal for Educational and Vocational Studies, 1 (5), 422-427.

Papastergiou, M. (2009). Digital Game-Based Learning in high school Computer Science education: Impact on educational effectiveness and student motivation. Computers and Education, 52(1), 1-12. https://doi.org/10.1016/j.compedu.2008.06.004

Plump, C. M., \& LaRosa, J. (2017). Using Kahoot! in the classroom to create engagement and 
active learning: A game-based technology solution for eLearning novices. Management Teaching Review, 2(2), 151-158.

Purba, L. S. L., Sormin, E., Harefa, N., \& Sumiyati, S. (2019). Effectiveness of the use of online games Kahoot! chemical to improve student learning motivation. Jurnal Pendidikan Kimia, 11 (2), 57-66. https://doi.org/10.24114/jpkim.v11i2.14463

Putra, P. D. A., \& Iqbal, M. (2014). Implementation of Digital Comic to Improve Creative Thinking Ability in Integrated Science Study. Icmse, April, 71-74. https://doi.org/10.13140/RG.2.1.4299.7286

Sahin, M. (2010). Effects of Problem-Based Learning on University Students' Epistemological Beliefs About Physics and Physics Learning and Conceptual Understanding of Newtonian Mechanics. Journal of Science Education and Technology, 19, 266-275.

Saleh, S. (2014). Malaysian students' motivation towards Physics learning. European Journal of Science and Mathematics Education, 2(4), 223-232.

Sulisworo, D. (2018). Blended Learning: Improving Student's Motivation in English TeachingLearning Process. International Journal of Languages' Education, 1 (Volume 6 Issue 1), 163-170. https://doi.org/10.18298/ijlet.2434

Sumarni, R. A., Bhakti, Y. B., Astuti, I. A. D., Sulisworo, D., \& Toifur, M. (2020). The Development of Animation Videos Based Flipped Classroom Learning on Heat and Temperature Topics. Indonesian Journal of Science and Mathematics Education, 3(3), 304-315.

Wichadee, S., \& Pattanapichet, F. (2018). Enhancement of performance and motivation through application of digital games in an English language class. Teaching English with Technology, 18(1), 77-92.

Wulandari, P., Mujib, M., \& Putra, F. G. (2016). Kahoot-Based Learning Game to Improve Mathematics Learning Motivation of Elementary School Students. Al-Jabar: Jurnal Pendidikan Matematika, 7(1), 101-106. http://ejournal.radenintan.ac.id/index.php/aljabar/article/view/134/124

Yilmaz, R. (2017). Exploring the role of e-learning readiness on student satisfaction and motivation in flipped classroom. Computers in Human Behavior, 70, 251-260.

Zarzycka-Piskorz, E. (2016). Kahoot it or not?: Can games be motivating in learning grammar? Teaching English with Technology, 16(3), 17-36. 